\title{
Polarization of Regional Economic Development in Croatia: Trends and Challenges in a New Geographic Reality*
}

\author{
Vera Pavlaković-Koči and Dane Pejnović
}

\begin{abstract}
This paper examines how the proposed conceptualization of Croatia's regional economic development, Koncepcija regionalnong gospodarskog razvitka Republike Hrvatske (1999), addresses the challenges of Croatia's uneven economic development. While the problems of Croatia's lagging regions have been addressed, the conceptualization contains controversies regarding what should be the guiding principles of regional policy - targeted or balanced regional economic development. The proposed conceptualization represents a mixture of neoliberal thinking about the key actors in regional economic development, principles of European Union regionalism and the socialist-era legacies. Consequently, it lacks clarity in several key aspects. A specific challenge is the existing multiciplicity of regional and socials interests as well as the limitations of regional economic development based on rigid administrative-territorial units.
\end{abstract}

Key words: polarization of regional economic development, targeted regional economic development, balanced regional economic development, Croatia.

\section{Polarizacija regionalnog ekonomskog razvoja u Hrvatskoj: tredovi i izazovi nove geografske realnosti}

Ovaj rad analizira predloženu Koncepciju regionalnog gospodarskog razvoja Republike Hrvatske (1999) prvenstveno sa stanovišta rješavanja problema neravnomjernog gospodarskog razvoja. Iako polazi od postojeće prostorne stvarnosti, određene izrazitim jazom između polova polariziranog razvoja i ruralne periferije, predloženom koncepcijom nije izrijekom definiran vodeći princip - ciljani razvoj ili usklađeni regionalni razvoj. Ona predstavlja kombinaciju neoliberalnih ideja o ulozi glavnih aktera u ekonomskom razvoju regije, principa regionalizma iz Europske Unije, te naslijeđa socijalistickog razdoblja. Rezultat toga je da ima obilježja sinkretizma, zbog čega joj nedostaje jasnoća u bitnim aspektima. Specifični izazov za budući regionalni razvoj predstavljaju i diferencirani regionalni i društveni interesi u suvremenoj Hrvatskoj kao i ogarničenje koje proizlazi iz rigidne admistrativno-teritorijanle podjele kao osnovice za regionalni gospodarski razvoj.

Ključne riječi: polarizacija regionalnog ekonomskog razvoja, ciljani gospodarski razvoj, uravnoteženi regionalni gospodarski razvoj, Hrvatska.

\footnotetext{
*An earlier version of this paper was presented at the conference: Remapping the Southern Tier of post-Socialist States:Politics/ Economics/Environment/Identity. Sponsored by: National Science Foundation, Russian, Central Eurasian and East European Specialty Group of the Association of the American Geographers, Department of Geography at the University of Wisconsin, Madison, Department of Geography at the University of Ljubljana and Department of Geography at the University of Primorska. Portotož, Slovenia, June 8-11, 2004.
} 


\section{INTRODUCTION}

Concern with differential regional growth rates is not a new phenomenon, although the regional debates are considerably more robust since the 1990s. They involve advocacy, design and implementation of new geo-economic units, believed by their proponents to be more suitable for the economic and non-economic realities of our time. According to Markusen (2002), three somewhat contradictory trends are propelling movements towards the development of regional policies. First is exemplified by the European project of regional integration into a super-national economic union. In the process of creating the European Union, issues of regional development and equity have been highlighted. Huge new funds ${ }^{1}$ have been created for regional programs with a primary objective to reduce disparities between the advantaged and disadvantaged regions. The second trend is the world-wide counter-tendency of devolution of responsibilities and taxing powers towards lower levels of government. The process of sub-national region-building is driven in part by optimism about the superior ability of regional and local governments to more successfully address regional differential growth rates in an increasingly globally-oriented world than central governments. This trend is evident in a wide range of countries, from industrial powers like Britain to newly industrialized countries such as South Korea and to developing countries including Nicaragua and former Soviet-sphere nations. Underneath these contradictory trends is a third trend, characterized with a resurgence of interest in regional solutions in which the metropolitan region - "city-state" - is considered the primary building block of the economy (Storper 1997, Scott 1998 cited in Markusen 2002).

\section{EXPERIENCES FROM PERIPHERY}

By the end of the 1990s, more than one hundred countries have instituted marketoriented structural reforms (Chakravorty 2003). The overwhelming evidence on policy reforms and the relationship between the opening of markets and bilateral or multilateral assistance, has led Chakravorty (2003) to conclude that the economic development policy at the national and local levels has overwhelmingly been guided by the ideology of markets. Citing recent evidence from a number of countries - Russia (Fedorov 2002), China (Fan 1995, Gustafsson and Shi 2002, Kanbur and Zhang 2003), India (Chakravorty 2000, Gosh et al. 1998), Indonesia (Akiata and Lukman 1995, Aswicahyono et al. 1996, Sjoholm 2000), and Thailand (Ahuja et al. 1997, Daniere 1996) - Chakravorty (2003) argues that divergence in development levels at the sub-national scale rather than convergence among sub-national regions has become the norm. Furthermore, he contends, the mounting evidence suggests that globalization has been associated with both increased peripheralization of countries on the international level and regions at sub-national scales.

Pernia and Quising (2003) examined whether economic openness ${ }^{2}$ influenced regional development and more specifically, poverty reduction in Phillipines. On the whole it appears that economic openness is beneficial to regional economic growth and via growth to poverty reduction. Nevertheless, the authors conclude, trade openness by itself cannot be relied upon to bring about more balanced regional development. Global influences tend to follow the pre-set pattern of economic development: foreign direct investment goes to 
regions with good physical infrastructure, human capital, favorable policy environment, and high prospect for economies of agglomeration.

The experiences of South-East European countries that have recently been accepted into the European Union is particularly relevant for Croatia. Croatia's neighbor, Hungary, often praised as one of the most successful transitions from the socialist to capitalist economy, experienced unequal development and widening of regional differences. According to Andor (2000), some parts of the country are becoming integrated into the international flows, while others are left idle in the conditions of high unemployment and industrial decline. The regions that benefited from the new geography are the capital city and the zones to the west of it. All the major foreign investments in the automotive industrysuch as General Motors, Suzuki and Audi, are located in northwestern Hungary. He concluded that Hungary, like many other semiperipheral countries, is more inclined toward the extremes of neoliberalism than those at the core of the world system. While industrial policy occasionally appears on the agenda, regional policy in Hungary, according to Andor (2000), is insignificant in comparison to issues like privatization, price reforms and the attraction of inward investment.

Unlike Hungary, Slovenia has a clearly defined policy of balanced regional development (Regional Development in Slovenia 2004). Mirroring the European Union's regional policy, the Balanced Regional Development Law was introduced in 1999, and since then represents the basis for Slovenia's regional development policy. Under the overarching goal of achieving balanced development of all Slovenia's regions, the policy limits the role of foreign direct investment to partnerships with regional institutions and companies. Potential partnerships include areas such as exchange of knowledge and information, strengthening of managerial capacities, programming, lobbying and networking, investments in R\&D projects, joint project development in economic, social, environmental, educational and cultural fields, and forming consortiums with Slovene companies. The implementation of the policy so far has encountered numerous problems particularly at the regional level. Among the most serious is the overall weak financial situation of municipalities with limited local budgets coupled with the lack of experienced staff, lack of experience with regional development thinking within municipalities as well as the lack of risk capital and local private co-financing (Regional Development in Slovenia 2004).

In lieu of these developments, this paper examines the challenges of and strategies for regional economic development in Croatia.

\section{HOW POLARIZED IS REGIONAL ECONOMIC DEVELOPMENT IN CROATIA?}

Pronounced internal regional differentiation has been one of the persistent characteristics of Croatian territory (Vresk 1996, Toskić and Ilić 1997, Toskić and Njegač 2003, Sić 2003). Differences in Croatia's economic development are in part the consequence of objective differences in physical-geographical basis and the given transportation and locational advantages for development, although they also reflect neglect of potential opportunities. In particular, delayed construction of transportation links and other infrastructure has caused slower growth and overall lagging (Žuljić 1992). 
Pejnović (2003) used seven demographic and socio-economic characteristics as indicators of differences in regional development among Croatia's administrative regions: population size, investment in non-residential structures, ${ }^{3}$ percent of economically active population, percent of employed population, and employed population in primary, secondary and tertiary sector. The analysis was conducted at two levels: (a) the existing administrative organization by county, i.e., županias and (b) the proposed territorial organization into five macroregions. ${ }^{4}$

The analysis has confirmed the expected correlation between the population distribution and polarization of economic activities. On one side are counties characterized by a high concentration of population, developed labor functions and more intense socioeconomic transformation. On the other side are counties with traditional division of labor and an aging population. ${ }^{5}$

The most economically advanced part of Croatia encompasses the City of Zagreb and the Zagreb County (situated in Central Croatia). Split-Dalmatia County (central part of Southern Croatia) follows with two counties in Western Croatia, namely the Primorje-Gorski Kotar County and Istra County (Figure 1). Split-Dalmatia County (in Central Dalmatia) stands out as Croatia's secondary regional development hub. The City of Zagreb is Croatia's primary growth pole, accounting for 18 percent of the total population, 19 percent of the total number of employed persons and 67 percent of all investments in Croatia. Together with the surrounding Zagreb County, the Zagreb region accounts for close to 25 percent of the total population, 27 percent of the total number of employed persons and 70 percent of the total investments.

In contrast, the least favorable characteristics of contemporary regional economic development can be seen in the peripherally located counties with less developed central settlements. First and foremost, this pertains to Croatia's largest problem-region, LikaSenj County, whose central settlement cannot even be ranked as a sub-regional center. Additional members of the club of the six most disadvantaged counties are: ViroviticaPodravina and Požega-Slavonija in Eastern Croatia, Bjelovar-Bilogora in North Croatia, Vukovar-Srijem in most eastern part of Croatia bordering Serbia, and Šibenik-Knin, in South Croatia. Together these six counties account for 30.6 percent of the total territory, 15.3 percent of the total population, 14.2 percent of the total employment, but only 3.4 percent of the total investment. The six most disadvantaged counties share a long term lagging in economic development, which has been exacerbated by material destruction of infrastructure during the war of 1991-1995. Pejnović (2003) echoes Žuljić'(1982) argument that the economic regress is closely related to the absence of stronger urban centers in those regions. The active population is still largely involved with the primary sector (agriculture, forestry). When combined with other less developed counties the economically disadvantaged regions represent about 47 percent of the total territory and 28 percent of the total population of Croatia.

A number of Croatian scholars agree that, in spite of many missed opportunities, the most dynamic socio-economic development in Croatia occurred under the influence of industrialization since the mid-twentieth century during the period of the Yugoslav federation. The intensity of social restructuring was reflected in a reduced number of people 


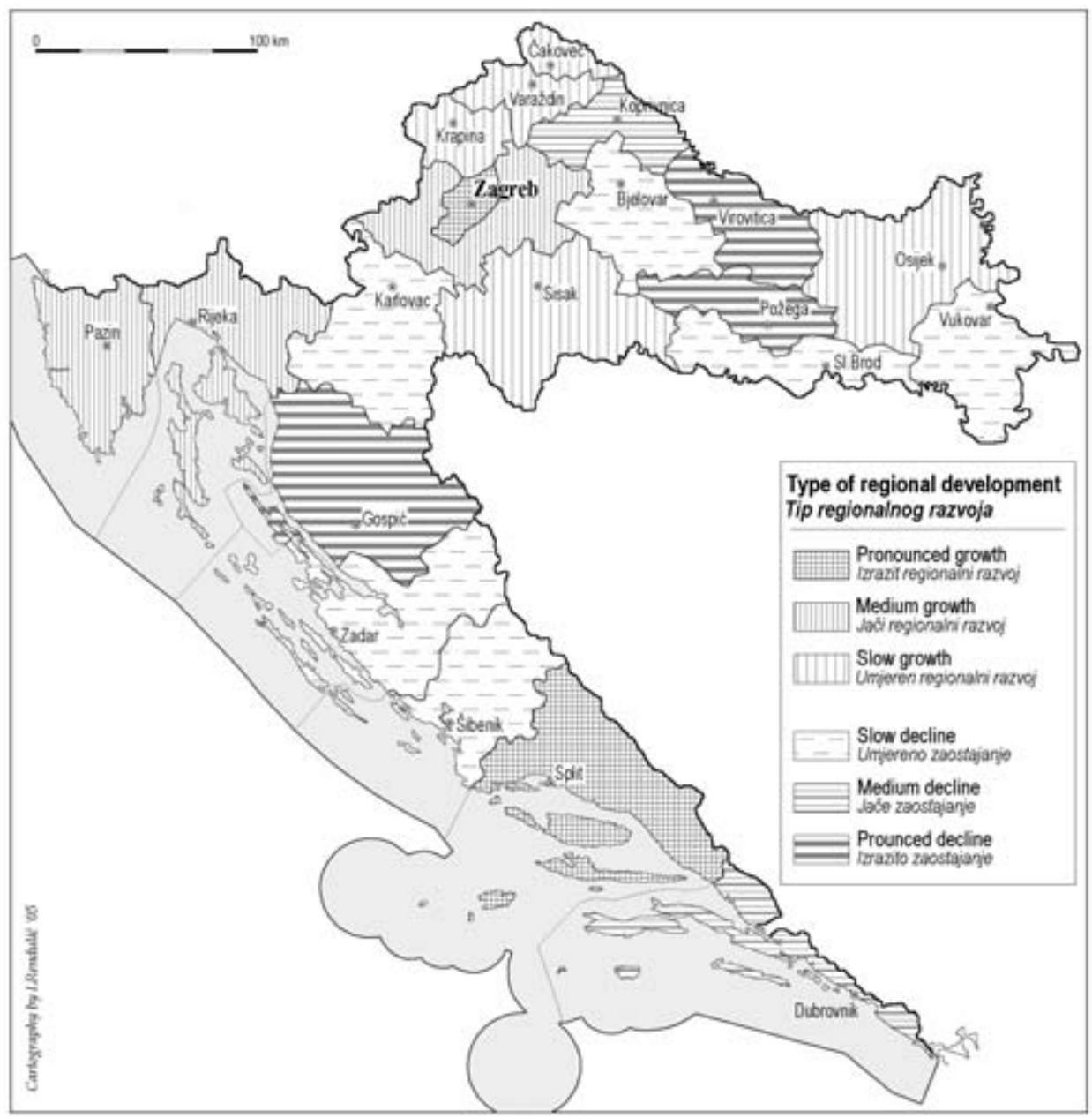

Fig. 1 Croatia's counties by relative degree of regional development in 2001

Sl. 1. Hrvatske županije prema stupnju regionalnog razvoja 2001. godine

Source: Pejnović, D. Polarizacija funkcije rada kao pokazatelj razlika u ragionalnom razvoju Hrvatske. (Polarization of labor functions as an indicator of Croatia's differentiated regional development), pp. 164-184. Treći kongres geografa Hrvatske ( ${ }^{\text {rd }}$ Croatian Geographical Congress), Zadar, Croatia, September (2003)

involved in agriculture between 1953 and 2001 by some 2,000,000 or almost 90 percent. During this period, Croatia moved from being a less developed agricultural economy into a medium-range developed economy with poly-functional economic orientations (Pejnović 2003). A strong manufacturing base in combination with geographic position on the northwest-southeast transportation corridor helped Zagreb become the second-largest city in Yugoslavia and the leading economic center in Croatia (Žuljic 1992). The rapid socio-economic transformation during this period was accompanied by equally rapid spatial polarization. 
In particular, two policies from the period of Yugoslav federation had a long-lasting impact. Basic priorities, such as the construction of a major transportation network, were in the domain of the federal Yugoslav government. This is why Croatia during that time primarily developed the transport connections with Belgrade and East Europe, while connections with the coastal region were neglected (Žuljić 1992). Equally negative consequences for the development of Croatia resulted from state intervention in regional economic development in the form of redistribution of material resources from relatively better-to-do regions and successful economic actors to the lagging regions. Substantial resources from Croatia, as a relatively more developed republic, were politically redistributed to other less developed regions in other republics. Although, as noted by Žuljić (1992), the same politically motivated redistribution of resources for the purpose of equitable development was also practiced within Croatia.

The disintegration of Yugoslavia in the early 1990s and the establishment of several new independent countries redefined all of Croatia's boundaries and, consequently, a large number of municipalities and counties became border areas: 45 percent of all municipalities and 76 percent of a total of 21 counties. For some of them, the new international borders only reemphasized their peripheral position in relation to the core of the national territory, while for others it meant disruption of traditional economic ties with their natural hinterlands. Moreover, eight of the 16 border counties found themselves next to hostile neighbors and experienced considerable damage during occupation or transborder attacks.

A combination of factors in the early years of independence contributed to the fact that many opportunities for economic development were missed. As argued elsewhere (Pavlakovich-Kochi 2004), economic development was not an immediate priority of Croatia's government in the early 1990s. The national security and stabilization of international position were the primary focus of the new state. Only after these concerns were taken care of, Croatia was able to address the questions of economic development and growth. Even then, the focus was on the integration of individual regions into Croatia's national territory. In contrast, integration with Central and Western Europe, which might have been more beneficial for the economic development of Croatia as a whole, was of secondary importance for Croatia's political leadership. ${ }^{6}$

Some regions like Istra County have a more favorable position in the new European geography than the rest of Croatia (Haberl 1994). This favorable global position explains in part the County's ranking among more prosperous counties. In case of the Split-Dalmatia County, the renewed cross-border economic ties with its natural hinterland in Bosnia and Herzegovina, are also a positive factor of economic development

A major problem, as indicated by Pejnović' (2003) analysis is that the difference in economic development between more and less developed regions has substantially widened in the last decade. Different development trends have created different problems. On one side, in regions with faster economic and demographic growth, a question of sustainability has emerged. In the second group, depopulation and aging seem to be limiting the prospects for economic growth.

Differences in economic development are foremost reflected in differences in standards of living of the country's residents. Combined with ethnic composition, these 
real and perceived differences can become a dangerous platform for political discourse (Richardson and Sen 1996). There is no doubt that a more balanced spatial distribution of population and economic activities is a prerequisite for a more equitable socio-economic development, as pointed by Pejnović (2003) in the conclusion of his analysis. However, the question arises: is a strategy of balanced regional economic development feasible given a complex juxtaposition of economic transition, changing relationships on the European periphery and increasing globalization?

\section{NEW CONCEPTUALIZATION OF REGIONAL ECONOMIC DEVELOPMENT: BALANCING BETWEEN OLD AND NEW, REALITY AND VISION}

In 1999, a group of renowned economists, regional scientists and geographers associated with the University of Zagreb Economic Institute developed a proposal for a new conceptualization of regional economic development in Croatia (in the remainder of the text referred to as CRED). ${ }^{7}$ The 210-page report was prepared as a background document for an anticipated wide-ranging debate about a new regional policy. ${ }^{8}$

The theoretical underpinnings of the proposed conceptualization of Croatia's regional development reflect a mixture of neoliberal ideas, the European Union-style regionalism and a socialist-era legacy. The last two are sometimes blurred as both advocate, at least in principle, a balanced regional economic development.

CRED has embraced the notion that competitiveness in world markets is the engine of national economic growth and a basis for achieving higher levels of employment and standards of living. CRED also acknowledges that the achievement of competitiveness on international scale requires selective strategies at national, regional and local (macro, mezzo and micro) levels, i.e., the selection of regional advantages that are the most promising in that respect. Consequently, a "planning for economic development" (plan gospodarskog razvoja) has been replaced by "strategic vision" (orijentacija regije - vizija budućnosti). A regional strategic vision reflects a general market orientation and local government's focus toward strengthening of regional competitiveness.

CRED incorporates a new way of thinking about region as a platform where regional actors - firms, local government and other institutions -influence a region's economic development through collaboration and partnerships. CRED also acknowledges that the region's competitive success in markets is increasingly dependent upon non-material factors such as the quality of education, effectiveness of industrial organization, ability to constantly improve the production process, intensity of research and development, infrastructure and services, and quality of products. These are reflected in the region's productivity, exports and income. The region's growth is seen as a result of two interactive levels of restructuring: at the level of individual firms and region as a whole. ${ }^{9}$

The new concept requires cooperation between private and public sector and networking among all actors in economic development. Three groups of actors have been identified: (a) government (legislative and executive) at state, county, city and local 
level, (b) political organizations such as political parties, unions, civic interest groups, international organization, educational and cultural institutions, research institutions, church and church organizations, and (c) economic subjects and institutions including trade organizations, small and medium-sized firms, entrepreneurs, farmers, foreign firms representatives, domestic and foreign banks, insurance companies, domestic and foreign investment funds, chambers of commerce, associations of entrepreneurs, development agencies, and technology parks and incubators.

Foreign direct investment (FDI) is only marginally addressed as a source of funding for regional economic development. Indeed, in the 26-page summary, FDI is mentioned only twice; the representatives of foreign firms are included in one of the three main groups of actors of economic development, although FDI's role is seen primarily in form of cooperation and partnership with local and regional firms.

CRED identified seven guiding principles of a proposed regional development policy: (1) bottom-up approach, (2) decentralization, (3) subsidiary principle, (4) strengthening of competitive advantages, (5) horizontal development, (6) definition of region as economic and non-economic entity, and (7) cooperation between private and public sector. The subsidiary principle and horizontal development, in particular, reflect the European Union influence.

Although CRED strongly advocates the necessity of targeting the most promising sectors, firms and regions in order to increase competitiveness on the global scale, this issue remains rather controversial at the level of regional policy. CRED clearly states "it is important to recognize, in Croatia (as a whole) as well as on the county level, which sectors and activities have the conditions necessary for successful and competitive participation in international markets, and thus make adjustments in the development of the supportive physical, economic, technological and educational infrastructure." However, in its summary section, CRED restrains from explicitly favoring the targeted approach either on national or regional level. The obvious hesitancy in proposing more forcefully the targeted approach largely reflects a fear that Croatia's pronounced regional diversity and multitude of interest groups ${ }^{10}$ is likely to be interpreted as favoring one at the expense of other.

The targeted approach advocated in some parts of CRED contradicts the principle of "horizontal development" defined by CRED as a balanced support for all sectors, without favoring anyone in particular. This excludes the sectors that are identified as "strategically important for the country" such as: development of human resources, development of physical, economic, technological and scientific infrastructure, investment in research and development, spread of information technology, elimination of monopolies, and implementation of property rights. Among these, the development of human resources, infrastructure, technological and innovative development, and development of small and medium sized enterprises are all identified as "particularly strategically important."

Unlike neighboring Slovenia, Croatia's CRED does not explicitly propose a balanced regional development as its objective. In fact, CRED explicitly states that the assumption about a balanced development of all regions as optimal development for the whole economy is wrong (p.194). Yet, the issue of less developed and less advantaged regions has been specifically addressed among 15 "general goals." Among these, three goals 
pertain to the speeding-up of reconstruction of war-devastated areas, economic support for the most depressive and endangered areas and encouragement of investment in less developed counties. The two additional goals address the reduction of regional differences in employment levels and a general perception of the central government's neglect of less developed counties. ${ }^{11}$

Several of the 11 "specific development goals" deal with reduction of uneven regional development as well. One goal specifically aims to slow down the depopulation process on Croatia's islands, in remote mountainous and border areas through attraction of a younger entrepreneurial population and a more efficient use of local resources. Additionally, two goals specifically aim to achieve balanced development for the purpose of reducing stress on Croatia's main urban centers. The goal is to encourage the location of economic activities and opening of new jobs in regions with currently high unemployment and emigration rates. ${ }^{12}$

The role of state in the regional development of Croatia is still very important. However, according to CRED, a more effective implementation of the regional policy goals will require decentralization of some functions (i.e., responsibilities) from central government to regional and local level (county and city governments). A more direct role of state is seen in two basic areas: (a) central government support to areas devastated by the war, and (b) creating of favorable business environment, development of supporting economic infrastructure, raising the level of technological and innovative development, investment in new knowledge, and other support for the benefit of all firms and sectors. Specifically, the government should assist the firms and industry sectors in market exposure, encourage partnerships among firms, reduce institutional and administrative barriers and, in particular, help small- and medium-sized firms with access to knowledge and resources to adopt to necessary changes.

CRED identified three areas of specific responsibility of the national government. The first pertains to the encouragement of migration to peripheral areas devastated by war for the purpose of their economic revitalization. This is a part of the "homogenization process" of the Croatian national territory, identified as a "constant component of the overall Croatian development policy." The second refers to the national program for the development of islands designed to provide direct state investment in the infrastructure, improvement of socio-economic conditions, encouragement of re-population and support of sustainable development. The third area of direct involvement of the national government is the employment program in less developed areas.

\section{CONCLUDING REMARKS}

Croatia is a relatively small country with limited resources, economically weakened by a four-year war and for now left outside of the European Union. At all levels - national, regional and local - crucial decisions are required on how to invest limited resources in order to increase competitiveness in global economy. This is not a question of choice; this is a question of necessary adjustments to changing economic conditions at a global scale and in the context of the new European periphery, in particular. 
Because of different influences and a struggle to design regional economic development policy, which would accommodate to the specificities of Croatia's historical and geographical context, the proposed concept of regional development (CRED) contains some more and less obvious controversies. It attempts to distance itself from the socialist-era legacy, when the primary objective of the regional development policy was an "egalitarian development by means of redistribution of resources from higher developed regions to less developed regions." Instead, CRED encourages an alternative approach with a focus on the most promising regions as major contributors to the overall national economic growth.

Yet, the distinction between targeted approach and horizontal development as the main guiding principles is not clear. There is an obvious hesitancy toward adopting the targeted approach in fear of being interpreted as favoritism for a particular region or industry. It reflects a deeply embedded perception that every move in development of Zagreb, Rijeka or other relatively more advanced center is an unfair competition (Žuljić 1992). Building consensus above and beyond a multitude of regional and other interests will remain one of the main challenges for Croatia's regional development policy (Mihaljek 2001).

A rigid administrative-territorial division that serves as a basis for economic regions is another challenge for Croatia's regional development. Obviously, this concept is more in line with the European concept of regions, and it will only be strengthened as Croatia nears her acceptance in the Union. As noted by Žuljić (1992), the negative competition among regions is likely to rise when an objective regional differentiation needs to be translated into political-administrative organization, and in particular at the higher level of territorial organization. An alternative concept of region, which includes notion of a more fluid and dynamic organization of economic activities regardless of political-administrative boundaries, may be more efficient.

At present, the proposed CRED lacks clarity and in an attempt to be all-inclusive, has become an unrealistic task. As Porter (in Habiby 2004) advised, one of the main ingredients of a successful economic strategy for a region or state is to figure out what are the most clear, most obvious and compelling weaknesses and barriers, what are the most clear and obvious opportunities and growth engines, and focus the strategy on those. Major factors of failure are fragmentation of money, duplicative agendas and competing interests. Given Croatia's multiplicity of regional and social interests, it is of utmost importance to build collaborative structures not only within, but also more importantly, across regional administrative boundaries.

\section{NOTES}

1. The two main funds are the Structural Fund and the European Regional Development Fund (ERDF). The Structural Fund is the principal means by which the European Union supports the member states in their efforts to reach greater economic and social cohesion. This requires the reduction of disparities between the advantaged and disadvantaged regions in living standards, infrastructure provision and employment opportunities. The four components of the Structural Fund are: European Agricultural guidance and Guarantee Fund (EAGGF), European Social Fund (ESF), European Regional Development Fund (ERDF) and Financial 
Vera Pavlaković-Koči, Dane Pejnović - Polarization of Regional Economic Development in Croatia: Trends and Challenges in a New Geographic Reality

Instrument for Fisheries Guidance (FIFG). ERDF is the main instrument of the European Union's regional development policy. Its intention is twofold: (a) to help redress regional imbalances and (b) strengthen the economic potential of regions, support structural adjustment and growth and create permanent employment. It contributes to financing of productive investment, infrastructure investment and measures designed to develop the indigenous potential of regions. Source: Sweet, M.L. 1999.

2. Economic openness in Pernia and Quising (2003) study is represented by the ration of exports to gross regional product.

3. Includes investment in new non-residential construction as well as investment in expansion, reconstruction and modernization of existing facilities. It is used as a proxy for a synthetic indicator of a region's economic potential.

4. In accordance with European Union's Nomenclature of Spatial Units (NUTS), Croatia's territory is divided into five statistical regions. According to the NUTS standard, the entire territory of Croatia represents the level 1 region (NUTS 1). The regions at the second level (NUTS 2) are: Central Croatia, North Croatia, East Croatia, West Croatia and South Croatia. These five regions are based on a combination of geographical, historical and economic criteria. The third-level regions (NUTS 3) correspond to twenty županijas (counties) plus the City of Zagreb. Counties vary in size and population between the smallest with only 54,000 people (Lika-Senj County) to over 300,000 people (Zagreb County, Primorsko-Goranska County, Osijek-Baranja County, and Split-Dalmatia County). Outside this range is the City of Zagreb with population of 779,000 (2001).

5. Each of the 21 counties (including the City of Zagreb), was ranked on individual indicators and assigned the corresponding number of points, from 21 (highest number of points to 1 the lowest). The overall rank was determined on the basis of accumulated points. These composite ranks were further used to identify the overall level of regional economic development. Based on the number of points, six types of regional economic development were identified: three representing low, medium and high level of economic development, and three representing low, medium and high lagging in economic development. For more details see Pejnović (2003).

6. Specifically, the delay in resolving the Croatian-Slovenian boundary problem has shown how little understanding there was among Croatia's leadership of the importance of connecting with Central Europe. The delay gave Slovenia an opportunity to position herself as a primary link between Hungary and northern Adriatic by prioritizing construction of transportation links to her advantage. This lack of emphasis on the larger picture and the specific position within Europe's new periphery was reflected in the professional geographic literature as well. For example, at the 1993 symposium organized by Croatian geographers, only two out of a total of 18 papers explicitly discussed Croatia's position within the new geography of Europe. The majority of papers dealt with issues of ethnic structure, Serbian aggression, and relationships with the neighboring countries.

7. Baletić, Z., L. Bayer, S. Crnković-Pozaić, P. Filipić, Z. Froehlich, D. Hunjet, D. Jurlina-Alibegović, J. Ladavac, M. Lenardić, S. Malenković, J. Padjen, M. Polić, Z. Roca, N. Starc, I. Šimunović, L. Škuflić, I. Turčić, S. Zdunić and S. Žuljić. Edited by Zlatan Fröhlich. 1999. Koncepcija regionalnog gospodarskog razvitka Republike Hrvatske (Conceptualization of Regional Economic Development of the Republic of Croatia). Zagreb, Croatia: Ekonomski institut. The project was initiated by the Republic of Croatia Ministry of Economy. Other two participating institutions are the Institute for International Relations and the University of Split Economic Faculty.

8. As of today, the proposed CRED has not yet been formalized, although it has been considered the most comprehensive document that outlines the underlying principles, objectives and proposed instruments for a new regional policy.

9. Although the text of the proposal does not give credit to specific literature, it appears that the authors were influenced by works such as Porter's 1990 Competitive advantage of nations, Storper and Salais' Worlds of Production (1997) and Storper's 1997 Regional world.

10. Mihaljek (2001) argues that apart from historical division along regional lines, Croatia has a high degree of social fragmentation, which has led to the emergence of a large number of interests groups. Sharp divisions also exist within and among different professions (e.g., journalists, economists, artists). Consequently, argues Mihaljek, the existence of such a large number of interest groups makes the elaboration of a development strategy an especially difficult task. 
11. The remaining general goals are: development and implementation of Croatia-specific concept of sustainable development; increase of the total national income and education levels; encouragement of industrial restructuring process in some counties; strengthening of the competitive advantages of some regions and the entire economy; development of export-oriented counties; development of innovative and technology-based economy; development of dynamic local production systems as foundations for entrepreneurial environment in all counties; contribution to a faster growth of quality of life in Croatia; encouragement of the change of traditional decision-making structure regarding the creation and implementation of new, innovative models of government at all levels, and generation of foundations for getting closer to the European Union.

12. The remaining specific development goals include: attraction and utilization of transborder (international) resources for local development; protection and improvement of environment and other inherited or created resources for future development; building of identity of Croatian counties so that they can be recognized in Croatia and Europe; encouragement of creation of regional partnerships (local government, development and volunteer organizations), confidence and social cohesion; creation of models of regional development appropriate for the regional differentiation in Croatia and specific potentials; creation of coordinated approaches to regional development through partnerships between central government, local government and local development organizations, and creation of self-employed jobs with help of agencies for local development and other kinds of supporting economic infrastructure. Source: Baletić et al. (1999).

\section{BIBLIOGRAPHY}

Ahuja, V., B. Bidani, F.Ferreira, and M. Walton.1997. Everyone's miracle? Revisting poverty and inequality in East Asia. World Bank. Washington, D.C. (cited in Chakravorty, 2004).

Akita, T. and R.A. Lukman. 1995. Interregional inequalities in Indonesia: A sectoral decomposition analysis for 1972-92. Bulletin of Indonesian Economic Studies 31: 61-81. (cited in Chakravorty, 2004).

Andor, L. 2000. Hungary on the road to the European Union. Transition in blue. Westport, Connecticut: Praeger.

Aswicahyono, H.H., K. Bird and H. Hill. 1996. What happens to industrial structure when countries liberalize? Indonesia since the mid 1980s. The Journal of Development Studies 32: 340-63. (cited in Chakravorty, 2004).

Baletić, Z., L. Bayer, S. Crnković-Pozaić, P. Filipić, Z. Froehlich, D. Hunjet, D. Jurlina-Alibegović, J. Ladavac, M. Lenardić, S. Malenković, J. Padjen, M. Polić, Z. Roca, N. Starc, I. Šimunović, L. Škuflić, I. Turčić, S. Zdunić and S. Žuljić. Edited by Zlatan Fröhlich. 1999. Koncepcija regionalnog gospodarskog razvitka Republike Hrvatske (Conceptualization of regional economic development of the Republic of Croatia). Zagreb, Croatia: Ekonomski institut.

Chakravorty, S. 2000. How does structural reform affect regional development: Resolving contradictory theory with evidence from India. Economic Geography 76: 367-394. (cited in Chakravorty, 2004).

Chakravorty, S. 2003. Urban development in the global periphery: the consequences of economic and ideological globalization. The Annals of Regional Science 37: 557-367.

Daniere, A.1996. Growth, inequality and poverty in South-East Asia: The case of Thailand. Third World Planning Review 18: 373-396. (cited in Chakravorty, 2004).

Fan, C.C. 1995. Of belts and ladders: State policy and uneven regional development in post-Mao China. Annals of the Association of American Geographers 85: 421-449.

Fedorov, L. 2002. Regional inequality and regional polarization in Russia, 1990-99. World Development 30: 443-456. (cited in Chakravorty, 2004).

Gosh B., S. Marjit, and C. Neogi. 1998. Economic growth and regional divergence in India: 19960 to 1995. Economic and political Weekly 33: 1623-1630. (cited in Chakravorty, 2004).

Gustafsson, B. and L. Shi. 2002. Income inequality within and across counties in rural China 1988 and 1995. Journal of Development Economics 69: 179-204. 
Vera Pavlaković-Koči, Dane Pejnović - Polarization of Regional Economic Development in Croatia: Trends and Challenges in a New Geographic Reality

Haberl, O.N. 1994. Croatia and Germany in Europe, pp. 7-16 in Croatia-A New European State. Hrvatska - nova europska država. Proceedings of the symposium held in Zagreb and Čakovec, September 22-25, 1993. Zagreb: The University of Zagreb Department of Geography.

Habiby, A. 2004. Michael Porter on essential elements for regional competitiveness and the role of the inner city. Economic Development America, Spring: 6-8.

Kanbur, R. and X. Zhang. 2003. Fifty years of regional inequality in China: A journey through central planning, reform and openness. Paper presented at UNU WIDER Conference on Spatial inequality in Asia, March 2003. http://www.wider.unu.edu/conference-2003-1/conference2003-1.htm accessed on April 5, 2003.

Markusen, A. 2002. Two frontiers for regional science: Regional policy and interdisciplinary reach. Papers in Regional Science 81: 279-290.

Mihaljek, D.2001.Toward a long-term strategy of economic development of Croatia: Where to begin, what to do, and how to do it? Occasional Paper No.11 (June). Zagreb, Croatia: Institute of Public Finance. http://www.ijf.hr/ops/PDF/ijf-ocp11.pdf accessed on May 18, 2004.

Pavlakovich-Kochi, V. 2004. The Zagreb region at double doorsteps - Implications of a redefined boundary for regional development, pp. 91-108 in Challenged borderlands: Transcending political and cultural boundaries. Edited by Pavlakovich-Kochi, V., B.J Morehouse and D. Wastl-Walter. England and USA: Ashgate.

Pejnović, D. 2003. Polarizacija funkcije rada kao pokazatelj razlika u regionalnom razvoju Hrvatske. (Polarization of labor functions as an indicator of Croatia's differentiated regional development), pp. 164-184. Treći kongres geografa Hrvatske ( $3^{\text {rd }}$ Croatian Geographical Congress), Zadar, Croatia, September.

Pernia, E.M. and P.F. Quising. 2003. Trade openness and regional development in a developing country. The Annals of Regional Science. 37: 391-406.

Porter, M. 1990. The competitive advantage of nations. London: Macmillan.

Regional Development in Slovenia. General information. Implementing regional development policy in Republic of Slovenia. http://www.rda-ceda.net/partners/slovenia/slovenia-gi.html accessed on May 1, 2004.

Richardson, J.M. and S. Sen. 1996. Ethnic conflict and economic development: A policy oriented analysis. School of International Service, American University. http://www.american.edu/jrich/Richardson.ethnic. confl.html accessed on May 19, 2004.

Scott, A.1998. Regions and the world economy: The coming shape of global production, Competition and political order. Oxford: Oxford University Press (cited in Markusen, 2002).

Sić, M. 2003. Regional disparities in Croatia. Hrvatski geografski glasnik, 65/2: 5-28.

Sjoholm, F. 2000. Economic recovery in Indonesia: The challenge of combining FDI and regional development. Paper presented at the IRSA International Conference, Jakarata, Mimeo. (cited in Chakravorty, 2004).

Storper, M. 1997. The regional world: Territorial development in a global economy. New York: Guilford (cited in Markusen, 2002).

Storper, M.and R. Salais. 1997. The worlds of production. Cambridge, MA: Harvard University Press.

Sweet, M. L. 1999. Regional economic development in the European Union and North America. Westport, Connecticut: Praeger.

Toskić, A. and M. Ilić. 1997. Neka prostorna i hijerarhijska obilježja urbanog sistema Hrvatske. Hrvatski geografski glasnik, 59: 73-82.

Toskić, A. and D. Njegač. 2003. Changes in political and territorial organization and their impact on Croatia's urban system and regional development. Hrvatski geografski glasnik, 65/1: 7-24.

Vresk, M. 1996. Funcionalna struktura i funkcionalna klasifikacija gradova Hrvatske. Hrvatski geografski glasnik, 58: 51-67.

Žuljić, S. 1992. Značenje regionalizma u političkom ustrojstvu i razvoju Hrvatske, pp. 1-26 in Fröhlich, Z., J. Padjen and S. Žuljić (Eds.), Regionalizam u političko-gospodarskom ustrojstvu Hrvatske. Zagreb, Croatia: Ekonomski institut. 


\title{
SAŽETAK
}

\section{Polarizacija regionalnog ekonomskog razvoja u Hrvatskoj: tredovi i izazovi nove geografske realnosti}

\author{
Vera Pavlaković-Koči i Dane Pejnović
}

Novije analize regionalnog razvoja Hrvatske pokazuju da je od početka 1990-ih godina došlo do povećane polarizacije između ekonomski dinamičnijih i tradicionalno slabije razvijenih regija (Pejnović 2003). Takav porast dispariteta očituje se na dvije razine prostorne analize, na razini makroregija i županija, koje predstavljanu odgovarajuće planske regije. Izloženi zaključci potakli su na razmišljanje o mogućim pristupima prostorno differenciranom ekonomskom razvoju u novim uvjetima prelaska na tržišnu ekonomiju uz pojačanu konkurenciju medju državama u novo definiranoj periferiji Europe. Povezano s tim, Ann Markusen (2002) sažela je mnogobrojne modele u tri osnovne kategorije. Prvu predstavlja europski projekt regionalne integracije u supra-nacionalnu uniju u kojoj se posebna pažnja posvećuje ravnomjernom ekonomskom razvoju. U okviru toga utemeljen je niz posebnih fondova sa svrhom smanjenja postojećih dispariteta medju regijama. Drugu kategoriju, koja prevladava izvan Europske Unije, čine nastojanja prebacivanja odgovornosti za ekonomski razvoj na regionalne i lokalne vlasti, odnosno ostale aktere u regiji. Treća kategorija, koja se preklapa s prve dvije, odnosi se na vodeću ulogu metropolitanskih regija u cjelokupnom ekonomskom razvoju.

Iskustva većine tranzicijskih zemalja ukazuju da se politika regionalnog ekonomskog razvoja pretežito formira pod utjecajem ideologije tržista (Chakravorty 2003). Rezultat takve politike porast je razlika u ekonomskom razvoju medju regijama (Fedorov 2002, Fan 1995, Gustafsson and Shi 2002, Kanbur and Zhang 2003, Akiata and Lukman 1995, Aswicahyono et al. 1996, Sjoholm 2000, Ahuja et al. 1997, Daniere 1996), što navodi na zaključak da se povećava perifernost regija unutar nacionalnih granica kao i u globalnom kontekstu (Chakravorty 2003).

Andor (2000) je ustanovio da se sličan proces pojačanog diferenciranja događa i u susjednoj Madžarskoj kao rezultat nejednake integracije pojedinih regija u internacionalne tokove, uključujući i privlačenje stranog kapitala. Za razliku od Madžarske, Slovenija je 1999. godine donijela zakon kojim se eksplicitno formulira uravnoteženi regionalni ekonomski razvoj kao osnovni cilj regionalne politike. Provođenje zakona, medjutim, nailazi na niz poteškoća među kojima su nedostatak iskusnog osoblja u pitanjima ekonomskog razvoja na lokalnom nivou te ograničena materijalna sredstva u lokalnim zajednicama.

Naglašena regionalna diferencijacija u postignutom ekonomskom razvoju predstavlja jedno od perzistentnih obilježja hrvatskog prostora (Vresk 1996, Toskić and Ilić, 1997, Toskić and Njegač 2003, Sić 2003). Središnje pitanje postavljeno u ovom radu odnosi se izbor novog pristupa rješavanju ovog problema u kontektsu nove političke i ekonomske stvarnosti. Nedavno predložena Koncepcija regionalnog gospodarskog razvitka Republike Hrvatske u izradi Ekonomskog instituta (1999) poslužila je za analizu nacrta novog pristupa.

Teorijska podloga predložene koncepcije predstavlja mješavinu neoliberalnih ideja, utjecaja regionalizma u duhu Europske Unije, te nasljeđa iz doba socijalizma. To je jedan od razloga što sadrži nejasne i kontroverzne postavke glede izbora ciljanog ravoja nasuprot ravnomjernog razvoja. Ciljani razvoj podrazumijeva izbor regije, industrije ili poduzeća koji imaju najveću vjerojatnost za uspješnu konkurenciju na globalnom (ili nacionalnom) planu. Takav pristup zahtijeva fokusiranu strategiju praćenu fokusiranim investicijama. Nasuprot tome, ravnomjerni razvoj zahtijeva veću ulogu agencija središnje vlasti i prelijevanje sredstava u slabije razvijene regije. 
Vera Pavlaković-Koči, Dane Pejnović - Polarization of Regional Economic Development in Croatia: Trends and Challenges in a New Geographic Reality

Kao dodatni izazovi u primjeni nove koncepcije regionalnog gospodarskog razvoja Hrvatske posebno se izdvajaju dva aspekta. Prvi proizlazi iz složenih regionalnih i društenih interesa (Mihaljek 2001) koji otežavaju strategiju ciljanog razvoja interpretirajući je kao favoritiziranje pojedine regije ili sektora (Žuljic 1992). Drugi, možda još jači, izazov proizlazi iz koncepcije gospodarskog razvoja unutar rigorozne administrativno-teritorijalne podjele koji je u suprotnosti s modernim konceptom regije kao dinamične organizacije gospodarskih aktivnosti bez obzira na administrativne granice.

Received (Primljeno): 2005 - 10 - 5

Accepted (Prihvaćeno): 2005 - 10 - 25

Vera Pavlaković-Koči, Ph.D., Director of Regional Development, Office of Economic and Policy Analysis, and Adjunct Associate Professor, Department of Geography and Regional Development, The University of Arizona, P.O. Box 210458, Tucson, AZ 85721-0458, U.S.A. e-mail: vkp@email.arizona.edu

Dane Pejnović, Ph. D.

Associate Professor, Department of Geography, The University of Zagreb, Marulićev trg 19/II, Croatia. e-mail: dapejno@geog.pmf.hr 
